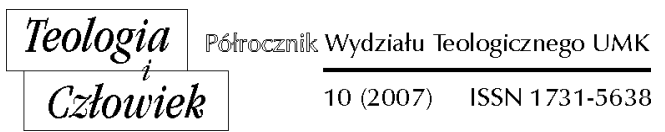

KS. ARTUR NIEMIRA*

WŁOCŁAWEK

\title{
OD DYKTATURY RELATYWIZMU DO ETYKI WIARY - BENEDYKTA XVI PROPOZYCJA ETYCZNA DLA EUROPY
}

W homilii podczas Mszy św. rozpoczynającej ostatnie konklawe, ówczesny dziekan Kolegium Kardynalskiego, kard. Joseph Ratzinger, postawił diagnozę współczesności, w której przyszło żyć Kościołowi. Stwierdził wówczas, że relatywizm, czyli zdanie się na każdy powiew nauki, zdaje się być jedyną postawą godną współczesności. Jeszcze mocniej zabrzmiały dalsze słowa homilii. Kardynał Prefekt powiedział: „Ustanawiany jest rodzaj dyktatury relatywizmu, która nie uznaje niczego za pewnik, a jedynym miernikiem ustanawia własne ja i jego zachcianki" ${ }^{1}$. Nie bez powodu warto zwrócić uwagę na tę wypowiedź, szeroko wówczas komentowaną jako program przyszłego papieża. Jest ona $\mathrm{w}$ pewnym sensie pomostem pomiędzy myślą kard. Josepha Ratzingera, przekazaną Kościołowi w konkretnym momencie historii zbawienia, a propozycją Benedykta XVI skierowaną do współczesnego świata, zwłaszcza zaś do Europy, jako odpowiedź na sytuację moralną starego kontynentu. Mówiąc inaczej, w cytowanych

${ }^{*}$ Ks. Artur Niemira - absolwent Papieskiego Uniwersytetu Gregoriańskiego w Rzymie, prowadzi zajęcia na WT UMK w Toruniu, w WSD we Włocławku i Bydgoszczy, kanclerz Kurii Diecezjalnej we Włocławku.

${ }^{1}$ Homilia kard. J. Ratzingera podczas Mszy św. «pro eligendo Romano Pontefice». Ku «dojrzałości» wiary w Chrystusa, OsRomPol 274 (2005), nr 6, s. 30. 
słowach, przyszły papież streścił ocenę współczesnej kultury Zachodu, nazywając ją dyktaturą relatywizmu, i przeciwstawił jej odpowiedź, jaką przekazuje chrześcijaństwo: jest nią wiara w Jezusa Chrystusa².

Mogą dziwić tak ostre sformułowania i pojawić się wątpliwość: czy ta diagnoza, często stawiana zwłaszcza w odniesieniu do Europy, jest słuszna i dlaczego papież wykazuje tyle aktywności na polu przypominania Europie o jej tożsamości? Zapewne dzieje się to pod wpływem refleksji nad niezrozumiałym wysiłkiem budowania nowej moralności z pominięciem chrześcijaństwa oraz w wyniku obserwacji czegoś, co Benedykt XVI nazywa dziś „samozagładą" Europy ${ }^{3}$. To rozminięcie się chrześcijaństwa z Europą, której tożsamość wyrosła na gruncie wiary w Jezusa Chrystusa, zwróciło uwagę wybitnego teologa Josepha Ratzingera, późniejszego prefekta Kongregacji Nauki Wiary, a następnie papieża Benedykta XVI.

Dlaczego Benedykt XVI interesuje się Europą i ona wciąż go niepokoi? Zanim podjęta zostanie próba wstępnej odpowiedzi na to pytanie jedna obserwacja. Nieczęsto można spotkać teologa dogmatyka w takim stopniu interesującego się teologią moralną, jak Joseph Ratzinger. Ten papież, dogmatyk z wykształcenia, w swojej refleksji na temat wiary z pasja stawia pytania natury moralnej i poszukuje na nie odpowiedzi. To ciekawe, ale trudno znaleźć książkę, artykuł czy wypowiedź Benedykta XVI dotykającą chrześcijańskiego credo, w której papież nie postawiłby pytań o konsekwencje etyczne wyznawanej wiary. Zerwanie więzi pomiędzy wiarą i moralnością, prawdą i wolnością, kwestionowanie specyfiki chrześcijańskiej w teologii moralnej, odłączenie się od duchowości, położenie nacisku na racjonalny charakter katolickiej moralności w duchu oświeceniowych wartości, sprawiło głębokie zainteresowanie się tego teologa, a dziś Następcy św. Piotra, właśnie teologią moralną.

Co do pierwszej części pytania, a więc słuszności postawionej diagnozy, stwierdzić należy, że w różnych momentach historii Europa była wystawiana na próbę swojej wierności korzeniom chrześcijańskim i stawiana przed pytaniem o własną tożsamość. Dla przykładu zwrócić należy uwagę na rok 1989 i upadek komunizmu. Myliłby się ten, kto by sądzil, że ów rok zapoczątkował nowy „złoty wiek” chrześcijańskiej wiary. Spuścizną czasów komuni-

\footnotetext{
${ }^{2}$ Powyższa refleksja wpisuje się w główny nurt troski Kościoła o tożsamość Europy, wyrażającej się chociażby w nauczaniu poprzednika Benedykta XVI. Jan Paweł II wybrał jako przewodni temat specjalnego zgromadzenia Synodu Biskupów dla Europy oraz adhortacji apostolskiej Ecclesia in Europa słowa: „Jezus Chrystus żyjący w swoim Kościele źródłem nadziei dla Europy" (Ecclesia in Europa, nr 1).

${ }^{3}$ Por. J. Peres Asensi, Etyka wiary w dziełach Josepha Ratzingera, Warszawa 2006, s. 17-18.
} 
stycznych w Europie stało się dziedzictwo spustoszonych dusz ${ }^{4}$, w których zamiast chrześcijańskiej wiary, intratniej prezentowały się ideologie liberalizmu, radykalnego indywidualizmu, ateizmu wraz z niejasnym mistycyzmem religijnym, agnostycyzmem i synkretyzmem religijnym. Zamiast chrześcijańskich podstaw, w Europie zakorzenił się relatywizm, a wiara nieugruntowana i niedojrzała pozwalała na pogoń za nowinkami ideologicznych prądów i modnymi sposobami myślenia, co przełożyło się na postawy etyczne.

Druga część pytania dotyczy zainteresowania Europą przez obecnego papieża. Odpowiedź, jaką można by sformułować, wiąże się z jego imieniem nawiązującym do osoby św. Benedykta, patriarchy monastycyzmu zachodniego, współpatrona Europy. Jak objaśnił sam papież, Benedykt miał wpływ na rozpowszechnianie się chrześcijaństwa na całym kontynencie i dlatego jest „zasadniczym punktem odniesienia dla jedności Europy i z mocą przypomina o niezbywalnych chrześcijańskich korzeniach jej kultury i cywilizacji" ${ }^{\prime \prime}$. Streszczając tę myśl, dochodzimy do pointy odpowiedzi na postawione pytanie: Benedykt XVI nie może nie interesować się Europą, troska o odnowę moralną starego kontynentu wypływa niejako z samej natury misji, której wypełnienia się podjął przybierając imię świętego patrona. Mówiąc krótko: Europa św. Benedykta z Nursji dziś jest Europą papieża Benedykta, jest jego Europą.

Już z tych wstępnych obserwacji rysuje się obraz naszej zachodniej cywilizacji. Naruszenie fundamentów etycznych wyrosłych na chrześcijaństwie niesie z sobą rozbicie kultury europejskiej i zamiast obiecywanej wolności przynosi dyktaturę relatywizmu wymierzoną wprost $\mathrm{w}$ samego człowieka. Można więc śmiało powiedzieć, że Benedykt XVI usiłuje przywrócić Europę jej samej i Chrystusowi. Dlatego zastanawiając się nad propozycją etyczną Benedykta XVI dla Europy przeżywającej napięcie pomiędzy dyktaturą relatywizmu a odnową moralną należy przyjrzeć się trzem kwestiom: kryzysowi kultury europejskiej, chrześcijaństwu w kryzysie kultur i przedstawić etykę wiary jako propozycją dla Europy.

\section{KRYZYS KULTURY EUROPEJSKIEJ}

Wolność i samowystarczalność - to słowa, które u Benedykta XVI funkcjonują jako klucz do zrozumienia rozłamu rozwijającego absolutną

${ }^{4}$ Por. J. Ratzinger, Wprowadzenie w chrześcijaństwo, Kraków 2006, s. 5-6.

${ }_{5}^{5}$ Audiencja generalna na placu św. Piotra. Imię nowego Papieża, OsRomPol 274 (2005), nr 6, s. 16. 
sprzeczność pomiędzy nauką i religią, rozumem i wiarą w kulturze europejskiej, naznaczając ją kryzysem moralnym ${ }^{6}$. Przyjrzyjmy się pokrótce analizie kondycji zachodniej cywilizacji poczynionej przez Benedykta XVI.

W swojej refleksji nad przyczynami kryzysu kultury europejskiej Benedykt XVI stwierdza, że Europa była kiedyś kontynentem chrześcijańskim, ale właśnie jako kontynent chrześcijański stała się też kolebką nowego racjonalizmu naukowego. Interesujące $\mathrm{w}$ tym kontekście stają się związki chrześcijaństwa ze starym kontynentem. $Z$ jednej strony chrześcijaństwo, choć nie wywodzi się ono z Europy, to właśnie tutaj otrzymało swoje kulturalne i intelektualne znamię. $Z$ drugiej jednak, ta Europa, zwłaszcza od czasów oświecenia, rozwinęła racjonalizm, który choć doprowadził do spotkania kontynentów i kultur, narodów i tradycji, to stał się także ścieżką rozwoju kultury, która „W nieznany dotąd sposób wyklucza Boga z publicznej świadomości”, negując Go lub twierdząc, że Jego istnienia nie da się udowodnić ${ }^{7}$. Niezwykle mocno brzmi papieskie stwierdzenie o kulturze, która na nieznaną dotąd skalę wyklucza Boga z publicznej świadomości, marginalizuje Go, izoluje, wyrzuca z życia państw, nawet odmawia wzmianki, że nasz kontynent był chrześcijański. Dzieje się tak dlatego, że ów racjonalizm, mówiący o niemożliwości udowodnienia istnienia Boga, spycha Go do obszaru subiektywnych wyborów, a więc mających marginalne znaczenie dla życia wspólnot, państw czy narodów. Racjonalizm oświeceniowy zakłada bowiem, że rozumne jest tylko to, co można udowodnić za pomocą eksperymentu. Według takiej metodologii, wiara nie jest rozumna. Także moralność, której taką drogą udowodnić się nie da, ale która mimo wszystko jest jakoś potrzebna, żeby przetrwać, musi podlegać regułom kalkulacji, choć w tej koncepcji jako kategoria sama w sobie znika. Kategoria dobra znika, gdyż nie ma już nic obiektywnie dobrego czy złego, wszystko zależy od sytuacji, od kalkulacji, od możliwych do przewidzenia następstw ${ }^{8}$. Jest $\mathrm{w}$ tym podstawowy błąd, który nie uwzględnia tego, iż dla moralności rozumność ma ogromne znaczenie, ponieważ moralność chce komunikować się i musi być komunikatywna, aby mogła stać się częścią wspólnego dialogu całej ludzkości. Zwłaszcza że rozumność jako cecha moralności wymaga wejścia w dialog również tam, gdzie moralności odmawia się miejsca relatywizując dobro czy zło?.

${ }^{6}$ Por. M. Pera, Wprowadzenie. Propozycja, w: J. Ratzinger, Europa Benedykta w kryzysie kultur, Częstochowa 2005, s. 21.

${ }^{7}$ Por. J. Ratzinger, Europa Benedykta w kryzysie kultur.., s. 46-47.

${ }^{8}$ Por. tamże, s. 47.

${ }^{9}$ Por. J. Ratzinger, Il rinnovamento della teologia morale: prospettive del Vaticano II e di Veritatis splendor, w: L. Melina, J. Noriega, Camminare nella luce. Prospettive della teologia morale a partire da Veritatis splendor, Roma 2004, s. 45. 
Człowiek Zachodu spowodował więc rozłam, czy separację, która miałaby polegać na przekonaniu, że w zetknięciu prawdy naukowej z prawdą wiary, autentyczną wiedzą jest tylko wiedza naukowa, gdyż wiara nie jest wiedzą $w$ dosłownym znaczeniu lecz wierzeniem. Stąd obiektywna i powszechna może być tylko wiedza naukowa; wiara posiada charakter wyłącznie prywatny i subiektywny. Nietrudno zauważyć praktyczne konsekwencje takiego rozłamu. Postulat wolności nauki domaga się wolności także od wszelkich zasad moralnych i od jakiegokolwiek ograniczenia natury religijnej. Wystarczy więc, że nauka „wie”, tym samym nic nie ma prawa stanąc na przeszkodzie temu, aby „mogła”. W sposób wyraźny jest to zauważalne wówczas, gdy nauka tworzy technikę: nauka wie, technika może, nauce wolno wiedzieć, więc technice wolno móc. Ów podział zapoczątkował inne: prawda wiary i prawda nauki, prawda moralności i prawda prawa, prawdy Boże i prawdy państwa, prawdy publiczne i prawdy prywatne ${ }^{10}$. Nigdzie nie musiała i nie mogła zachodzić pomiędzy nimi harmonia. Przejście od „byćc do „musieć” zostało nazwane błędem logicznym. Pytania o to, co mogę poznać i co muszę robić nie są już ze sobą powiązane. Rozłam, o którym mowa, stał się kulturalnym i politycznym sztandarem tego, co nazywamy dziś oświeceniem ${ }^{11}$.

Racjonalizm oświeceniowy $\mathrm{w}$ zetknięciu $\mathrm{z}$ postępem cywilizacyjnym powoduje wyrzeczenie się moralności na rzecz techniki i nauki, ponieważ uważa, że moralność jest irracjonalna. Poczucie coraz większej kontroli nad światem zdaje się utwierdzać człowieka w przekonaniu, że posiadł zdolność panowania nad sobą samym, nad swoim życiem i uniezależnił się od wymagań natury etycznej. Pójście drogą rozumu, a moralność jest przecież nieracjonalna, domaga się oderwania od wymiaru etycznego na rzecz samowystarczalności. Ta samowystarczalność przejawia się np. w zdolności do „zbudowania" człowieka, który nie musi już przychodzić na świat jako dar Stwórcy, ale jako produkt naszego działania, zgodnie z życzeniem składającego zamówienie i zdolnościami wykonawcy. Życie zaczyna być przedmiotem kontraktu, umowy handlowej respektującej wolność rozumianą w kategoriach praw rynku. Taki człowiek nie musi już myśleć o sobie jako o stworzeniu na obraz Boży, czy jako darze Bożym, co przecież rodzi pewną zależność typu Bóg - stworzenie, ale dominuje inna zasada: człowiek nie jest obrazem Boga lecz człowieka. Papież pyta: tylko jakiego człowiek $^{12}$ ?

\footnotetext{
${ }^{10}$ Por. M. Pera, dz. cyt., s. 24-26.

${ }^{11}$ Por. tamże, s. 26.

12 Por. J. Ratzinger, Europa Benedykta w kryzysie kultur.., s. 42.
} 
Ten jeden choćby przykład pomaga zrozumieć przekonanie papieża, że wzrostowi możliwości technicznych nie odpowiada równoczesny rozwój siły moralnej. Co więcej, odnosi się wrażenie, że ta siła wraz z postępem zmalała. Brak równowagi pomiędzy „wiem” a „mogę", rozłam pomiędzy rozumem a moralnością uwidacznia, że gwarantem wolności i godności nie są techniczne systemy bezpieczeństwa, ale moralna siła człowieka ${ }^{13}$.

Wobec tego, czym jest nasza europejska kultura, której sparaliżowaną postać obserwujemy? Papież zapytuje, czy kultura europejska oznacza tylko cywilizację techniczną, czy raczej trzeba mówić o cywilizacji posteuropejskiej, jako że świat wartości właściwy dla Europy sięga swego kresu i właściwie znikną ze sceny dziejowej? Pytania papieża zdają się być uzasadnione. Europa dziś jawi się wewnętrznie pusta, sparaliżowana, niezdolna do obrony. Symptomem takiego stanu rzeczy jest choćby brak woli przetrwania. Papieża dziwi właśnie to poddanie się, rezygnacja z walki o przetrwanie. Dzieci nie są nośnikiem przyszłości ale przejawem zagrożenia dla teraźniejszości. Jako źródło takiego kryzysu można wskazać relatywizm: rozmywanie się pewników na temat Boga, człowieka i świata oraz zanik poczucia nienaruszalnych zasad moralnych ${ }^{14}$. W odniesieniu do rodzącego się życia proces ten widać dość wyraźnie.

Zderzenie dwóch kultur (chrześcijańskiej i oświeceniowej) ujawniło się choćby w sporze dotyczącym konstytucji europejskiej, zwłaszcza w kwestii odniesienia do Boga oraz wzmianki o chrześcijańskich korzeniach Europy. Choć mówi się, że Kościoły miały w niej zagwarantowane prawa, to jednak w zakresie fundamentów Europy nie było żadnego miejsca dla śladów, jakie w nich zostawiły. Benedykt XVI stwierdza, że argumenty idące za taką postawą są raczej maskowaniem prawdziwych problemów, niż przekonującym uzasadnieniem. Mówi się, że wzmianka o korzeniach chrześcijańskich raniłaby uczucia niechrześcijan zamieszkujących Europę, ale tymczasem oczywiste jest, że w zapisie chodzi przede wszystkim o fakt historyczny dotyczący chrześcijańskich korzeni, któremu trudno zaprzeczyć. Zdaniem papieża jest tutaj raczej lęk przed ewentualnymi skutkami na przyszłość uznania faktu, bo stwierdzenie o korzeniach chrześcijańskich wskazuje na istniejące źródła kierunku moralnego ${ }^{15}$. Papież stawia pytania o to, kogo miałoby obrażać podobne stwierdzenie? I odpowiada: muzułmanie nie czują się zagrożeni zasadami chrześcijańskiej moralności, ale cynizmem

\footnotetext{
${ }^{13}$ Por. tamże, s. 43.

${ }^{14}$ Por. J. Ratzinger, Europa. Jej podwaliny dzisiaj i jutro, Kielce 2005, s. 21-24.

${ }^{15}$ Por. tenże, Europa Benedykta w kryzysie kultur..., s. 49.
} 
zlaicyzowanej kultury; Żydzi nie czują się znieważeni odniesieniem do chrześcijańskich korzeni Europy, bo sięgają one Góry Synaj; wyznawców innych religii nie obraża odniesienie do Boga, ale raczej budowanie Europy bez $\mathrm{Niego}^{16}$.

Mamy do czynienia z ucieczką przed własną tożsamością $\mathrm{w}$ europejskich narodach, z poczuciem wyobcowania w ludziach, czyli z kryzysem kultury. Proces, o którym mowa staje się zauważalny właśnie w odrodzeniu się islamu na naszym kontynencie. Jego ekspansja na kraje Europy wiąże się z procesami laicyzacji i odcinania się od fundamentu, na którym można by budować tożsamość Europy. Rośnie bowiem przekonanie, że chrześcijaństwo nie jest $\mathrm{w}$ stanie stworzyć istotny dla narodów duchowy fundament. Europie wymknął się on z rąk. Dlatego, pomimo materialnego wzrostu, Europa zdaje się być skazana na powolną agonię ${ }^{17}$. Prawdziwość tego stwierdzenia objawiła się $\mathrm{z}$ całą siłą $\mathrm{w}$ okresie zmasowanej krytyki Benedykta XVI przez islamskich radykalistów po jego wykładzie na uniwersytecie w Ratyzbonie. Bezsilność i agonalny stan zdolności do samoobrony Europy wyraził się w głuchej ciszy europejskich przywódców i Parlamentu Europejskiego, który zagnany w ślepą uliczkę oświeceniowych zasad wolności i tolerancji nie zdobył się na głos obrony i solidarności z papieżem.

Wracając jednak do konstytucji: powody tego podwójnego „nie” dla odniesienia do Boga i dla wzmianki o korzeniach chrześcijańskich, zdaniem papieża, są głębsze. U ich podstaw jest założenie, że podstawą tożsamości europejskiej mogłaby być tylko kultura oświeceniowa w swym najbardziej radykalnym wydaniu. Jej fundamentalną wartością jest wolność, jako kryterium oceny wszystkiego. Tylko że taka wolność prowadzi w prosty sposób do sprzeczności i absurdów trudnych do pogodzenia. Jak bowiem pogodzić pragnienie wolności kobiet, domaganie się tzw. praw dla kobiet, z prawem do życia nienarodzonych? Jak pogodzić wolność słowa z wolnością religijną, na przykład $\mathrm{w}$ przypadku podejścia do homoseksualizmu. Dziś właściwie już nie można powiedzieć, że homoseksualizm jest, jak naucza Kościół, obiektywnym nieładem w kształtowaniu ludzkiego istnienia, bo byłby to zamach na wolność. Staje się oczywiste, że to źle określona koncepcja wolności, stojąca u podstaw kultury oświeceniowej, w którą wpycha się Europę, niesie ze sobą tak naprawdę ograniczenie wolności ${ }^{18}$.

\footnotetext{
${ }^{16}$ Por. tamże, s. 50.

${ }_{17}$ Por. J. Ratzinger, Europa. Jej podwaliny dzisiaj i jutro..., s. 20.

${ }^{18}$ Por. tenże, Europa Benedykta w kryzysie kultur..., s. 52.
} 
Wewnętrzne sprzeczności kultury oświeceniowej nakręcają spiralę coraz bardziej absurdalnych wolności, z których nie wiadomo jak się potem wycofać, czy jak je wzajemnie pogodzić. Sama koncepcja praw człowieka w połączeniu ze źle zrozumianą koncepcją wolności, łamiącą podstawowe przymioty tych praw, doprowadza do konfliktu, a na liście praw człowieka pojawiają się coraz bardziej egzotyczne sformułowania. Jak uniknąć bowiem zderzenia pomiędzy prawem do życia, najbardziej fundamentalnym prawem człowieka, a prawem do aborcji wnoszonym na listę praw człowieka? Albo, jak zdobyć się na powagę i ukryć zdziwienie, gdy słyszy się przedstawicieli organizacji feministycznych deklarujących prawem człowieka prawo do używania środków antykoncepcyjnych, a lekarskie ostrzeżenia przed grożącym wskutek ich używania ryzykiem dla zdrowia a czasem życia, łamaniem praw człowieka? Mówiąc o prawach człowieka zapomina się o wypływających z nich obowiązkach. Tymczasem, osadzone w obiektywnych wymogach natury, prawa człowieka wiążą się z jego obowiązka$\mathrm{mi}$, a podmiotem tych praw jest zawsze każdy człowiek $^{19}$.

Współcześnie, w Europie poszanowanie godności i wolność przysługuje tylko nielicznym ludziom: silnym, bogatym i wpływowym. Kryzys kultury europejskiej jest więc kryzysem dotykającym najgłębszego wymiaru człowieczeństwa, kryzysem poszanowania godności człowieka, kryzysem szacunku wobec człowieka i w konsekwencji kryzysem praw człowieka. Przysługują one tylko niektórym, gdyż ich rozumienie nie wiąże się z tym, że przysługują one człowiekowi dlatego, że jest człowiekiem, a więc nie wypływają z ludzkiej godności, ale za ich fundament uznaje się fakt przyznania ich komuś przez grupę ludzi decydujących kogo za człowieka uznać, zakrywając się szyldem reguł panujących w świecie demokracji. Mamy tu do czynienia z argumentem siły, gdzie o godności słabszych decydują silniejsi i ci silniejsi ustalają kryterium człowieczeństwa.

Podsumowując, papież wyraźnie stwierdza, że kultura europejska potrzebuje korzeni chrześcijańskich. Odcięcie się od korzeni chrześcijańskich nie jest wyrazem tolerancji szanującej inne kultury, ale absolutyzacją myślenia radykalnie sprzecznego z innymi kulturami ludzkości. Jest to konflikt kultur będący sporem pomiędzy radykalną emancypacją człowieka a wielkimi tradycjami kulturowymi. Punktem wyjścia tej tolerancji chcącej wymazać Boga z życia publicznego jest relatywizm uznający siebie za posiadacza ostatecznego poznania rozumu i nazywający całą resztę jako prze-

${ }^{19}$ Por. Benedykt XVI, Orędzie na Światowy Dzień Pokoju 2007, nr 12. 
starzałą fazę ludzkości ${ }^{20}$. Czy rzeczywiście chrześcijaństwo jest nie do pogodzenia ze współczesną kulturą i czy istnieje jakaś droga zjednoczenia wiary $\mathrm{z}$ rozumem?

\section{CHRZEŚCIJAŃSTWO W KRYZYSIE KULTUR}

W rozumieniu papieża zasługą oświecenia było i jest, że ponownie zaproponowało fundamentalne wartości chrześcijaństwa, takie jak wolność i prawda, i oddało właściwy głos intelektowi. Tutaj Benedykt XVI dochodzi do być może zaskakującego stwierdzenia, że „w tym sensie oświecenie wywodzi się z chrześcijaństwa i zrodziło się nieprzypadkowo i wyłącznie w ramach wiary chrześcijańskiej. [...] Sobór Watykański II w Konstytucji o Kościele w świecie współczesnym ponownie uwydatnił tę głęboką zgodność chrześcijaństwa z oświeceniem”21, starając się pokazać, że Kościół nie boi się nowoczesności i wychodzi ku współczesnemu światu. Chrześcijaństwo jest religią Logosu, a więc wiarą w Boga Stworzyciela, od którego pochodzi cała rzeczywistość. Ten świat nie powstał w wyniku ślepej siły, tego, co nierozumne, gdzie rozum jest tylko produktem ubocznym, ale świat powstał $\mathrm{w}$ wyniku rozumu i jest $\mathrm{w}$ konsekwencji ukształtowany według jego kryteriów i celów. Innymi słowy, to rozum stwórczy pokazuje człowiekowi drogę̨2 Ż̉yąc wiarą pochodzącą od Logosu chrześcijanin staje się otwarty na wszystko, co jest naprawdę racjonalne i tą drogą poszukuje prawdy i dobra. Dlatego też Europa nie powinna bać się Chrystusa, ponieważ przyznając $\mathrm{Mu}$ centralne miejsce, zyskuje prawdziwe pojednanie pomiędzy historią i rozumem, pomiędzy fides i ratio. Osoba Jezusa nie jest obca refleksji rozumowej. On przemawia do człowieka, ukazując mu prawdę także $\mathrm{w}$ epoce postmodernistycznej ${ }^{23}$.

Papież składa świeckiej Europie propozycję. Chodzi o odwrócenie pewnego aksjomatu. $\mathrm{W}$ epoce oświecenia zasadnicze normy moralne określano mówiąc, że powinny one być tak stworzone, żeby można je zastosować nawet, gdyby Bóg nie istniał. Propozycja na dziś jest następująca: kto nie potrafi znaleźć drogi do Boga, powinien starać się przynajmniej tak żyć, jak gdyby Bóg istnia2 ${ }^{24}$. Taką radę dawał już Pascal swoim niewierzącym

\footnotetext{
${ }^{20}$ Por. J. Ratzinger, Europa Benedykta w kryzysie kultur..., s. 62-63.

${ }^{21}$ Tamże, s. 66.

${ }^{22}$ Por. tamże, s. 67.

${ }^{23}$ Por. J. Ratzinger, Il rinnovamento della teologia morale..., s. 43.

${ }^{24}$ Por. tenże, Europa Benedykta w kryzysie kultur..., s. 70.
} 
przyjaciołom. Tą drogą nikt nie zostałby ograniczony w swojej wolności. Apel papieża ma wymiar egzystencjalny. W chwili, gdy nie ma żadnego pewnego odniesienia $\mathrm{w}$ poszukiwaniu zasad moralnych potrzeba ludzi, którzy za pomocą oświeconej i przeżywanej wiary uczyniliby Boga wiarygodnym dla współczesnej Europy. Potrzeba świadectwa. Negatywne świadectwo chrześcijan, którzy o Bogu mówili, a żyli przeciwko Niemu otworzyło drzwi dla niewiary i wyrządziło przysługę w rozwoju kultury oświeceniowej w jej najbardziej radykalnej postaci ${ }^{25}$.

Słabość naszego chrześcijańskiego świadectwa tkwi chyba w tym, że boimy się wyjść na zewnątrz, dawać świadectwo tam, gdzie promuje się moralnie luźny styl życia, gdzie oczernia się wiarę, wyśmiewa z Kościoła, boimy się jasno zadeklarować, że nie można zgodzić się na to, co sprzeciwia się naszej wierze. Chrześcijaństwo w Europie znów schodzi niejako do katakumb: wierzący czują się jakby w mniejszości, osamotnieni, bo nie wypada dziś być większością. Dziś w Europie należy być mniejszością, by mieć prawa uznawane przez postępowy i cywilizowany świat. Dlatego Benedykt XVI nawołując do odwagi w dawaniu świadectwa zaznacza, że paradoksalnie, inaczej niż to jest dziś postrzegane, chrześcijańskie świadectwo może przysłużyć się pluralistycznym demokracjom Zachodu i poszerzyć w nich przestrzeń dla Boga ${ }^{26}$.

Propozycja Benedykta XVI stwarza płaszczyznę do poszukiwania zasad w sferze życia publicznego. Tam również potrzeba świadectwa. Mówi się nieraz, że katolik nie ma prawa do życia zgodnego z Ewangelią poza sferą prywatności. Paradoksalnie także do tego, co prywatne nie chce się dziś wpuścić Chrystusa, a co dopiero pozwolić opierać się na Nim w sferze działania publicznego. Chrześcijanin ma nie tylko prawo, ale i obowiązek do kierowania się zasadami Ewangelii w życiu publicznym i społecznym dla zbawienia świata. Lęk przed Ewangelią jest dziś tak silny, że każde przyznanie się do Chrystusa rodzi fobię posądzeń o nietolerancję. Tolerancyjne jest tylko to, co proponuje człowiekowi szczęście, zbawienie bez Chrystusa. Obecność Boga w życiu publicznym przeszkadza. Przyzwolenie zaś na miejsce dla Boga w prywatnej opinii przy jednoczesnym wykluczeniu Go z przestrzeni publicznej nie jest tolerancją, lecz hipokryzją ${ }^{27}$. Zapomina się bowiem, że działanie, które w założeniu wyklucza Chrystusa, jest

${ }^{25}$ Por. tamże, s. 70.

${ }^{26}$ Por. A. Nichols, Myśl Benedykta XVI. Wprowadzenie do myśli teologicznej Josepha Ratzingera, Kraków 2006, s. 334.

${ }^{27}$ Por. Homilia Benedykta XVI z okazji inauguracji Synodu. Żyjmy moca Eucharystii, OsRomPol 279 (2006), nr 1, s. 8. 
działaniem bez miłości, a więc ostatecznie rani człowieka, bo uwolnienie się od miłości powoduje, że człowiek gotów jest uwolnić się od człowie$\mathrm{ka}^{28}$. Gdzieś tkwi rana, która zadaje ból najgłębszemu wymiarowi człowieczeństwa. Nieważne, że zagubionemu człowiekowi, zranionemu brakiem miłości proponuje się coś, co sprawi, że będzie jeszcze bardziej zraniony i zagubiony. Nie potrzeba takiej wolności, potrzeba odpowiedzialności; co $\mathrm{z}$ tego, że w imię tolerancji, skoro nie ma w niej miłości.

Tej kulturze rzekomo poszukującej wartości ogólnoludzkich w imię wolności i tolerancji Benedykt XVI rzuca wyzwanie. Stawka o jaką toczy się gra warta jest rozważenia. Człowiek niewierzący, który w motywację swojego działania, w motywację swoich wyborów, wolnych decyzji wpisuje zasadę „żyć, jak gdyby Bóg istniał”, staje się bardziej odpowiedzialny ${ }^{29}$. Postawa, jaką zdecyduje się przyjąć, nie będzie niosła w sobie ryzyka wykluczenia kogokolwiek, dzielenia osób na kategorie według jakichś kryteriów, nie będzie niosła ryzyka wystawienia się na zarzut o podeptanie ludzkiej godności. Mówiąc obrazowo, działanie według przyjętej zasady nie tylko gwarantuje poszanowanie wolności mojej, ale także każdego innego człowieka, bez obawy popełnienia błędu, co do uznania czyjegoś prawa do wolności. W konsekwencji niewierzący będzie musiał powiedzieć "tak" wierzącemu. Nie powie, że płód jest rzeczą, czy materiałem genetycznym, nie stwierdzi, że usunięcie płodu lub embrionu nie narusza żadnych praw, nie powie, że to, co technicznie możliwe, już przez ten fakt staje się również moralnie dozwolone, nie będzie mówił, że wartości chrześcijańskie nie są wartościami ludzkimi, nie będzie uznawał wyższości demokratycznych reguł nad odpowiedzialnością powiązaną z poszukiwaniem dobra i prawdy.

Dlaczego warto podjać takie wyzwanie? Bóg, zarówno dla wierzącego, jak i dla niewierzącego, choć odmienny w rozumieniu, to dla obu stanowi część ich kultury, historii i tożsamości. To właśnie ta kultura budowała przez wieki chrześcijański kontynent starej Europy, w której zasadą działania staje się ,jjak gdyby Bóg istniał”, gwarantująca wolność, równość, poszanowanie godności każdego, także niewierzącego, jak byśmy wszyscy byli dziećmi Bożymi. Marcello Pera, do niedawna marszałek włoskiego senatu, komentując papieską propozycję dla Europy przekonywał, że na podjęciu takiego wyzwania wszyscy zyskują: narody, prawodawstwo, zachodnia cywilizacja, już w samym punkcie wyjścia, nie licząc ożywienia, jakie kontynent europejski mógłby dzięki owej zasadzie przeżyć ${ }^{30}$.

\footnotetext{
${ }^{28}$ Por. DCE, nr 28.

${ }^{29}$ Por. M. Pera, dz. cyt., s. 35.

${ }^{30}$ Por. tamże, s. 37.
} 
Dlatego poważnie należy postawić pytanie o to, co może zagwarantować Europie przyszłość, przetrwanie jej duchowej tożsamości, czy też co może zagwarantować człowiekowi godność i odpowiadającą tej godności egzystencję. Odpowiedź Benedykta XVI jest wskazaniem na podstawowe elementy moralne, które powinny znaleźć się w propozycji etycznej odnowy Europy. Pierwszym elementem jest bezwarunkowość, z jaką powinna być przestrzegana godność każdego człowieka. Drugi element określający tożsamość europejską wskazany przez Benedykta XVI, to małżeństwo i rodzina. Małżeństwo monogamiczne jako podstawowa struktura relacji pomiędzy kobietą a mężczyzną i jednocześnie jako komórka kształtująca wspólnotę państwową nadało Europie jej szczególny profil. Żądania homoseksualistów uznania przez prawo ich związków za równe małżeńskim w tym kontekście rozważań nad europejską tożsamością jawią się jako wykroczenie poza obręb dziejów ludzkiej moralności. Ostatnim elementem jest poszanowanie świętości w sensie najwyższym, dla Boga, i szacunek dla religii. Wolno zakładać, że $\mathrm{z}$ tym szacunkiem znajdziemy się także $\mathrm{u}$ niewierzących. Gdy go nie ma, w społeczeństwie ginie coś bardzo istotnego. W Europie karom podlega znieważanie wiary Izraela, karze podlega człowiek znieważający Koran. Gdy idzie natomiast o Chrystusa i o to, co święte dla chrześcijan, najwyższym dobrem staje się wolność opinii i tolerancja. Tymczasem wolność poglądów ma swoje granice $\mathrm{w}$ tym, że nie wolno naruszać czci i godności drugiego człowieka. To nie jest wolność do deptania ludzkich praw. W ostrych słowach diagnozuje tę sytuację papież: „Kryje się tu jakaś nienawiść Zachodu do siebie samego, co jest zjawiskiem dziwnym i co można uznać za przejaw patologii" ${ }^{\prime 31}$. Europa nie lubi samej siebie, żeby przetrwać potrzebuje krytycznej samoakceptacji, a nie ucieczki od tego, co własne, od własnych wartości. Trzeba zachować stałe wartości, pewny punkt odniesienia dla konkretnych wyborów, a więc przerwać dyktaturę relatywizmu. Tym punktem odniesienia według Benedykta XVI ma stać się wiara.

\section{ETYKA WIARY - PROPOZYCJA DLA EUROPY}

Skoro propozycja etyczna Benedykta XVI dla Europy brzmi działać ,jak gdyby Bóg istniał" i domaga się poszanowania dla Boga, to należy zapytać o sens wiary chrześcijańskiej. Rodzi się bowiem pytanie, czy wiara jest postawą godną człowieka współczesnego, Europejczyka?

${ }^{31}$ Por. J. Ratzinger, Europa. Jej podwaliny dzisiaj i jutro..., s. 28-31. 
Najpierw należy spojrzeć na kwestię Boga. Chodzi bowiem o pytanie o początek i sens naszego istnienia. Ta kwestia nie powinna być obca człowiekowi opierającemu swoje działanie na podstawach racjonalnego poszukiwania odpowiedzi. Papież pyta, czy człowiek może zadowolić się życiem w postaci hipotetycznej, ,jak gdyby Bóg nie istniał", gdy tymczasem być może On istnieje? I nie chodzi tu tylko o problem teoretyczny. Kwestia Boga ma wymiar wybitnie praktyczny z konsekwencjami w każdej dziedzinie życia. W praktyce chodzi o wybór pomiędzy dwiema alternatywami: albo żyć, jak gdyby Bóg nie istniał (i wtedy z hipotezy, która może być nieprawdziwa uczynić fundament życia), albo żyć, jak gdyby Bóg istniał i w wyniku doświadczenia przekonać się o słuszności takiego wyboru $^{32}$. Znajomość Boga opiera się na zaufaniu ludziom, dla których Bóg stał się konkretnym doświadczeniem. To zaufanie staje się uczestnictwem, które potem jest weryfikowane w przeżytym doświadczeniu każdego z nas. Innymi słowy, aby przyjąć tę wiedzę bliźniego doświadczającego obecności Boga ja sam muszę się otworzyć na Boga. W tym sensie poznanie Boga jest bardziej osobiste niż wiedza, którą mam wspólną z technikiem, czy specjalistą $\mathrm{z}$ danej dziedziny. $\mathrm{W}$ doświadczeniu wiary musi nastąpić wejście $\mathrm{w}$ relację $\mathrm{z}$ Bogiem. Wiara $\mathrm{w}$ żywym spotkaniu przekształca się $\mathrm{w}$ poznanie, $\mathrm{w}$ „wiedzę". Człowiek wybierający alternatywę żyć ,jjak gdyby Bóg istniał" wierzy już nie z powodu słów kogoś, ale ponieważ pod wpływem osobistego doświadczenia wie, że Jezus jest Zbawicielem świata (por. J 4, 42) ${ }^{33}$.

W obliczu dyskusji nad etyczną propozycją dla Europy Benedykt XVI widzi, że konieczne jest oparcie się na fundamentach, które mają jako podstawową oś więź osobistą Boga z człowiekiem. Wiara jest więc fundamentem modelu etycznego proponowanego przez papieża Europie $\mathrm{w}$ epoce racjonalizmu oświeceniowego. Jest ona ostatecznym fundamentem życia moralnego rozwijającego się $\mathrm{w}$ relacji pozostawać - pojmować. Model pozostawać - pojmować: pojmowanie rzeczywistości rodzi się z wiary, która jest przyjmowana jako dar i tylko pozostając w niej, będzie można zrozumieć sens rzeczywistości ${ }^{34}$. Ten model „etyki wiary” Josepha Ratzingera daje prymat wierze, uważając ją za formę nowego poznawania, różnego od wiedzy naukowej i technicznej. Benedykt XVI broni wiary przed marginalizowaniem jej do sfery subiektywnej. Nie tylko umieszcza ją w tym samym środowisku, co rozum, ale wyrzuca wręcz modernizmowi pomniejszanie

\footnotetext{
${ }^{32}$ Por. tenże, Europa Benedykta w kryzysie kultur..., s. 110.

33 Por. tamże, s. 126-127.

${ }^{34}$ Por. J. Peres Asensi, dz. cyt., s. 73.
} 
znaczenia rozumu przez pozbawienie go wiary ${ }^{35}$. Wiara pomaga rozumowi, pomaga mu $\mathrm{w}$ otwarciu się na zasadniczą kwestię fundamentu całej rzeczywistości. Wiara nie przeszkadza rozumowi, ale go budzi, wyzwala i poszerza jego pole działania ${ }^{36}$.

Taka wiara jest nierozdzielna od życia. Wiara jest drogą życia, jakie rodzi się ze spotkania osobistego z Chrystusem. Jest także podstawą moralności chrześcijańskiej, ponieważ moralność jest wiarą przeżywaną jako droga. Specyfiką tej moralności jest postępowanie za Chrystusem ${ }^{37}$.

W obliczu więc kryzysu wiary i moralności Benedykt XVI proponuje Europie moralność, której centrum jest Chrystus i osobista relacja z Nim. Jest to droga dojścia do prawdy, a tym samym odszukanie fundamentu wolności. Prawda jest fundamentem i miarą wolności. Nie da się dojść do prawdy, a tym samym do wolności bez powiązania ich z pojęciem Boga, w którym zawiera się wymiar egzystencjalny doświadczenia wiary. Wiara jest silniejsza niż prądy, które przychodzą i odchodzą, dlatego tylko ona może stać się fundamentem, na podstawie którego Europa na nowo odnajdzie swoją tożsamość.

\section{ZAKOŃCZENIE}

Kryzys moralny przejawia się $\mathrm{w}$ naszym społeczeństwie tym, że pomyliło ono prawdę z opinią większości opierając się na relatywistycznej i sceptycznej demokracji. Propozycja etyczna Benedykta XVI zmierza do przywróceniu godności należnej życiu, sumieniu i wolności człowieka uzasadnionych w jedynej Prawdzie Jezusa Chrystusa ${ }^{38}$. Jego nauka wspiera istnienie wartości wspólnych $\mathrm{w}$ społeczeństwie pluralistycznym, ponieważ zbudowana jest na fundamencie nienaruszalnej godności człowieka i fundamencie wiary w Jezusa Chrystusa. Warto więc raz jeszcze podkreślić wyzwanie Benedykta XVI, którego skuteczność wiąże się ze świadectwem chrześcijan. Europa potrzebuje świadków. Świadkowie wiary budowali naszą europejską kulturę i tylko tą drogą może nastąpić odnowa moralna zachodniej cywilizacji. Tu otwiera się przestrzeń dla konkretnej obecności każdego z nas, wierzących. Zadaniem chrześcijanina w Europie jest żyć prawdą, którą jest Chrystus.

\footnotetext{
${ }^{35}$ Por. J. Ratzinger, Svolta per l'Europa?, Milano 1992, s. 83.

${ }^{36}$ Por. tenże, Dogma e predicazione, Brescia 1973, s. 90.

${ }^{37}$ Por. J. Peres Asensi, dz. cyt., s. 47.

${ }^{38}$ Por. tamże, s. 74.
} 


\section{DALLA DITTATURA DEL RELATIVISMO ALL'ETICA DELLA FEDE - LA PROPOSTA ETICA DI BENEDETTO XVI ALL'EUROPA}

\section{RIASSUNTO}

Nell'omelia tenuta il 18 aprile 2005 durante la Messa pro eligendo Papa, il Card. Joseph Ratzinger ha analizzato la situazione in cui vive la Chiesa di oggi. Ha ritenuto che il relativismo cioè il lasciarsi portare „qua e là da qualsiasi vento di dottrina” sembra essere "l'unico atteggiamento all'altezza dei tempi odierni" e che "si va costituendo una dittatura del relativismo che non riconosce nulla come definitivo e che lascia come ultima misura solo il proprio io e le sue voglia". Queste parole costituiscono un ponte tra il pensiero di Joseph Ratzinger sulla condizione morale dell'Europa e la proposta di Benedetto XVI per il nostro continente. Il papa ha giudicato la cultura moderna dell'Occidente nominandola "la dittatura del relativismo" e ha contrapposto a essa la risposta che il cristianesimo offre al mondo: la fede autentica in Gesù Cristo. 
